\title{
LORD KELVIN \\ and the Age of the Earth
}




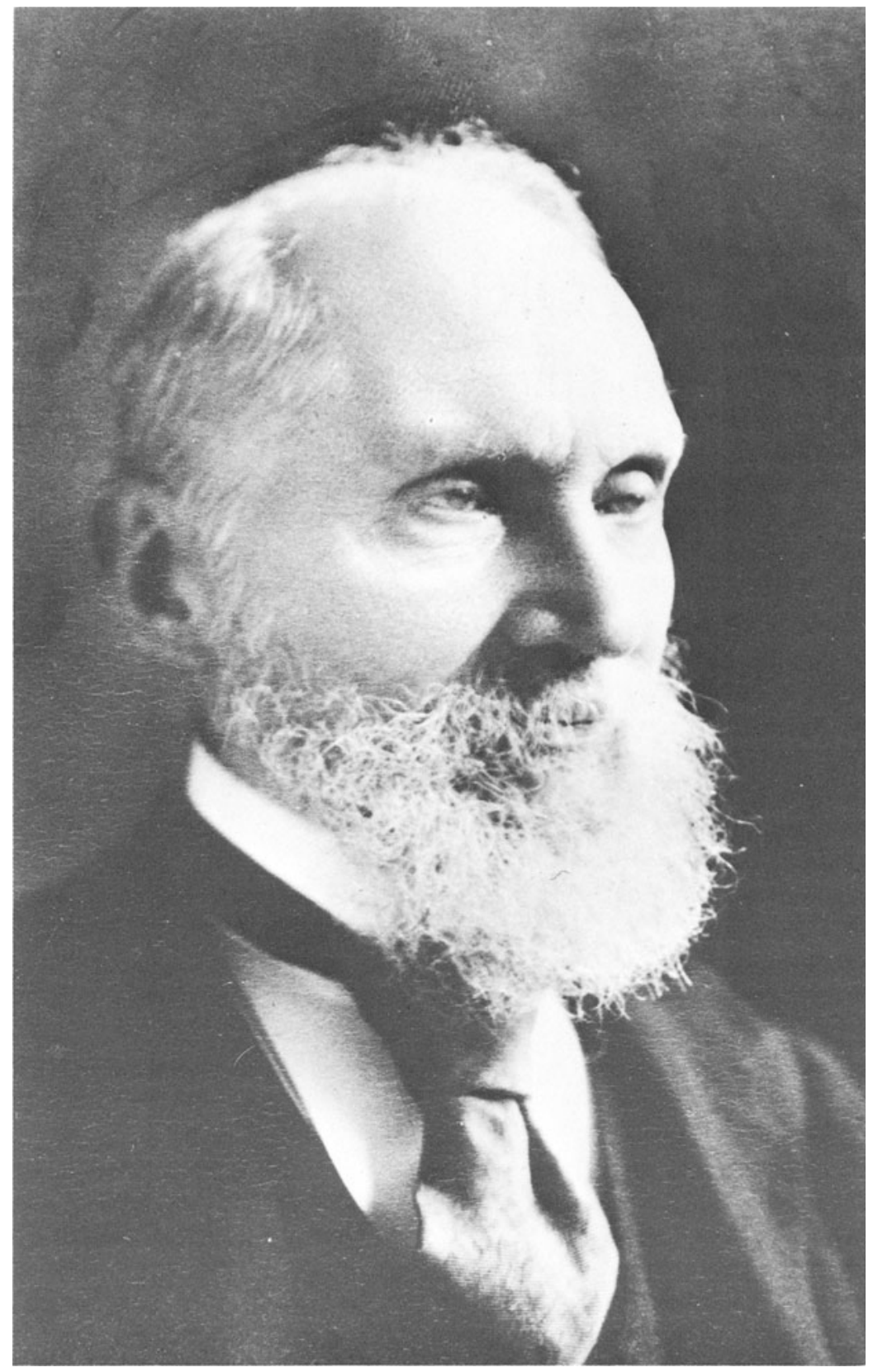




\title{
LORD KELVIN
}

\section{and the Age of the Earth}

\author{
JOE D. BURCHFIELD
}


(C)Science History Publications 1975

Softcover reprint of the hardcover 1st edition 1975

All rights reserved. No part of this publication may be reproduced or transmitted, in any form or by any means, without permission.

\author{
Published by \\ THE MACMILLAN PRESS LTD \\ London and Basingstoke \\ Associated companies in New York \\ Dublin Melbourne Johannesburg and Madras
}

SBN 333181093

ISBN 978-1-349-02567-1 ISBN 978-1-349-02565-7 (eBook)

DOI 10.1007/978-1-349-02565-7 
For Martha 


\section{Contents}

Preface ix ix

I Introduction $\quad 1$

Historical Background $\quad 3$

Measuring the Age of the Earth 12

$\begin{array}{ll}\text { References } & 18\end{array}$

II Kelvin and the Physics of Time $\quad 21$

$\begin{array}{ll}\text { Preliminary Speculations } & 21\end{array}$

$\begin{array}{ll}\text { Time and Thermodynamics } & 27\end{array}$

The Later Arguments $\quad 40$

The Age of the Earth and the Laws of Nature 45

References $\quad 53$

III Kelvin's Influence: The Initial Reception 57

$\begin{array}{ll}\text { Converts and Opponents } & 59\end{array}$

Kelvin, Darwin, and Wallace $\quad 70$

$\begin{array}{ll}\text { The Kelvin-Huxley Debate } & 80\end{array}$

$\begin{array}{ll}\text { References } & 86\end{array}$

IV The Triumph of Limited Time $\quad 90$

Geology and the Measurement of Time 96

Physics and the Limitation of Time 108

$\begin{array}{ll}\text { References } & 117\end{array}$

V Opposition and Controversy 121

Growing Discontent $\quad 122$

The Challenge $\quad 134$

The Loyal Opposition $\quad 144$

A Biological Postscript $\quad 156$

$\begin{array}{ll}\text { References } & 158\end{array}$

VI Radioactivity and the Age of the Earth 163

Kelvin Overthrown: Radioactive Heating 166

Radioactive Dating $\quad 171$

$\begin{array}{ll}\text { Geological Reaction } & 179\end{array}$ 
viii Lord Kelvin and the Age of the Earth

The Expansion of the Time Scale 190

The Report of the National Research Council

References

206

VII Conclusion

Bibliography

Index 


\section{Preface}

It takes a long time to prepare a world for man, such a thing is not done in a day. Some of the great scientists, carefully ciphering the evidences furmished by geology, have arrived at the conviction that our world is prodigiously old, and they may be right, but Lord Kelvin is not of their opinion. He takes the cautious, conservative view, in order to be on the safe side, and feels sure it is not so old as they think. As Lord Kelvin is the highest authority in science now living, I think we must yield to him and accept his view. He does not concede that the world is more than a hundred million years old. He believes it is that old, but not older.

Mark Twain, Letters from the Earth

The concern with determining the age of the earth in years appeared in the west with the birth of Christianity, but it was not until the second half of the nineteenth century that this concern developed into the subject of a full-scale scientific investigation. Between 1860 and 1930, however, the accepted estimate of the earth's age evolved from the virtually unlimited expanse of time demanded by Charles Lyell and his followers, through a series of ever more restrictive limits imposed by nineteenth century physics and geology, to the vast but quantitatively definable chronologies derived from radioactive dating. During that cycle, the question of the earth's age stirred heated debate, stimulated important studies in physics, astronomy, geology, and biology, and served as the focus for a fascinating interplay of personalities and hypotheses.

In the study presented here, I have traced the evolution of the conception of geological time by describing the theories and principles involved in the more important methods of calculation. In the process, I have also attempted to illustrate the importance of a conscious concern with quantification in the development of a scientific discipline. And finally, by concentrating upon the continuity of Kelvin's influence and the interaction between physics and geology, I hope that I have provided some insight into the way in which individual and collective 
preconceptions, the deference to authority, and the interactions between disciplines and personalities affect the development of scientific ideas.

It has been necessary, of course, to impose several important restrictions on the scope of my investigations. For one thing, I have concentrated upon the physico-geological problem of establishing a quantitative limit for the probable age of the earth rather than upon the nearly parallel but more exclusively geological problem of determining the relative ages of strata. I have also concentrated upon the interaction between only two branches of science, physics and geology, during the whole period under discussion. Biology and astronomy have been included when appropriate, but only in the case of Darwinian evolution, where the question of time is critical, is this discussion at all extensive. Religion, which was often central to the earlier debates over the earth's age, played a relatively insignificant part in the later controversies and has been considered here only when it had a definite effect upon scientific thought. And finally I have dealt almost exclusively with British scientists during the period before 1890 and primarily with British and American scientists thereafter.

This last restriction, which was imposed neither arbitrarily nor merely for convenience, deserves some explanation. The number of scientists actively pursuing the problem of geological time was never very large, and during the second half of the nineteenth century it was confined almost exclusively to a small group of British investigators. Geologists on the continent made impressive progress in the study of crystallography, mineralogy, stratigraphy, paleontology, and geomorphology, but with very rare exception they made little attempt to establish a quantitative geochronology. Continental physicists seem to have ignored the problem altogether. Furthermore, although I must admit that my research in Continental scientific literature-primarily French and German - was considerably less thorough than in British and American journals, the few studies I did find relied heavily upon British sources and differed little from their conclusions. American geologists, too, took their measure of time from their British colleagues. With a vast, largely undefiled geological laboratory stretching before them, they devoted themselves to exploration and observation rather than to speculation and theory-building. There were exceptions, of course, but in general it was not until near the end of the century that American geologists began to take an active part in the search for the age of the earth. 
It is difficult to say why the age of the earth should be so exclusively an Anglo-Saxon preoccupation. Friends, more learned in Continental geology than I, have offered some interesting speculations which as yet I have been unable to check adequately. I can, however, offer some admittedly speculative suggestions for why the question attained such prominence in England. In the first place, despite its growing professionalization, geology remained the British popular science par excellence throughout the nineteenth century. It consequently continued to attract the skill and efforts of amateurs like Kelvin, Huxley, and William Hopkins who were established masters in a variety of subjects and who could bring fresh points of view to bear on geological problems. Such diversity of knowledge was particularly valuable in the case of the age of the earth because, as it turned out, geological methods alone were not sufficient to establish an exact chronology. Another important factor was the character of British scientific organizations, particularly the geological societies and the British Association. These organizations provided extremely congenial forums for noted amateurs and for the interdisciplinary exchange of ideas. Such societies were not uniquely British, of course, but in the clubbish atmosphere of Victorian science they frequently attained their fullest development. Certainly in the case of the age of the earth, they served as the principal sounding boards for new ideas and the forums for discussion and debate.

One final word is perhaps in order to explain the inclusion of radioactive dating in what is primarily a study of Victorian science. The discovery of radioactivity undoubtedly marks a watershed in the investigation of geological time for it not only destroyed the basis for Kelvin's calculations, but supplied the tools for an entirely new approach to the problem. There are nonetheless valid reasons for considering the new methods as a continuation of the old. For one thing, Kelvin's influence remained strong throughout the first two decades of the twentieth century even among advocates of the new time scales revealed by radioactivity. And for another, the geologists themselves were most unwilling to abandon the techniques, hypotheses, and results that they had so laboriously compiled. Before the new time scale could be accepted, therefore, it had to be shown to be compatible with the record revealed by the crust of the earth itself. Thus to end my investigation with radioactivity's first challenge would leave the story half told, and indeed might serve to reinforce already existing misconceptions about the effect of the discovery of radioactivity upon geo- 
chronology. Furthermore, the debates generated by radioactive dating cannot be fully appreciated without an understanding of Kelvin's continued influence at the end of the nineteenth century. And finally, certain parallels exist in the study of the earth's age both before and after the discovery of radioactivity which will, I hope, give this study some significance beyond that accorded the simple investigation of an esoteric scientific problem. The role of preconceptions and authority in interpreting data, the validity of comprehensive theories based upon limited data, the influence of one science upon another, and the conflicts between them are, I believe, all subjects worthy of careful study.

I have accumulated many debts during the preparation of this book, more than I can ever properly acknowledge. There are several people and institutions, however, to whom I am especially indebted and to whom I offer a special thanks. William Coleman first read parts of this work as a dissertation at The Johns Hopkins University, and in the years since, he has continued to provide invaluable criticism and assistance as well as even more valuable encouragement. Rhoda Rappaport, Martin J. S. Rudwick, Alexander Ospovat, Leonard G. Wilson, and Paul A. Carter all read earlier versions of the manuscript and offered me the benefit of their knowledge and insights. I have been cheerfully assisted by the staffs of many libraries, particularly those of The Johns Hopkins University Library, the Northern Illinois University Library, the John Crerar Library, the Geology Library of the University of Illinois, the Library of Congress, and the University of Chicago Library. Countless others have helped through interlibrary loan. The Faculty and Board of Regents of Northern Illinois University have provided financial support through several faculty research grants. I am also particularly indebted to Miss Sue Reynolds and Mrs. Darla Woodward of the History Department staff at Northern Illinois University for their patient help in preparing the final drafts of the manuscript. And finally my greatest thanks are reserved for my wife, who sustained me both by her encouragement and her perceptive criticism, and for my children who bore with it all without really knowing why. 